\title{
THE DALIT CONTEXT
}

Harka Gurung

If You had to give me this birth

Why give me birth at all?

You cast me away to be born; you were cruel.

Where were You at the time of my birth?

Who did You help then?

Chokha says: O Lord, O Keshava, don't let me go.

Chokhamela

The Dalit Context

The above quotation and title of its source provide insight into two problems regarding the Dalit. First is their fatalistic attitude apparent from the above supplication to Lord Keshava, another synonym for Krishna. Since high castes lord over the Dalit through divine sanction, it is an exercise in futility. Second, the book title, From Untouchable to Dalit, illustrates terminological transition from specific to neutral one. That is, adoption of a general term, Dalit (oppressed), in place of Achhut (untouchable) that is both pejorative and illegal. The above two problems are very much germane to the Dalit discussion.

The Constitution of Nepal-1990 reaffirms the alignment of the state to Hindu ideology (Article 4.1). This means perpetuation of social exclusion of millions of low caste people with its economic and political ramifications. The mainspring of such inequality is the 
varna model of social stratification based on birth. The Sanskrit term varna has two literal versions: varna as colour and varnaashram as four stages of life. Although most ascribe the four-fold caste hierarchy (Brahman, Kshatriya, Vaisya, Sudra) to Manu's version as bodily parts of Brahma, there seems some racial (varna) basis to distinguish between the Aryan conquistadors and autochthonous peoples. Racial discrimination is generally considered to be based on color. Untouchability in Hindu caste system has also racial element as the ritual status of one's caste is also based on birth. Thus, the social exclusion of untouchable castes is also a form of racial discrimination'. This chapter attempts some clarification on the genesis, definition, population, and situation of Dalits in Nepal.

\section{Orientation}

Nepal at the periphery of the Hindustan plain was originally a congeries of tribal units. The earliest inroad of Hinduism was in $5^{\text {th }}$ century A.D. during the Lichhavi rule in Kathmandu Valley. Since the $11^{\text {th }}$ century, Hinduistic orientation in the country was as a reactionary effect of Muslim conquest of India. In Kathmandu Valley, Jasyasthitiraj Malla (1382-1395) introduced an elaborate system of 64 castes among the Newar. In Gorkha, Ram Shah (16051633) adapted this model into a less structured form. Thereafter, Sen rulers of Palpa claimed to be 'Hindupati' (champions of Hinduism). These theocratic tendencies were basically as a bulwark against Muslim hegemony in Mughal India. But with the decline of the Mughal, there emerged another power in the plains: the British rule with Christian faith. Such a historical compulsion led to the primacy of Brahman orthodoxy in the Nepalese court to construct a Hindu haven against Mughal (Muslim) and British (Christian) regimes. Therefore, the designation of Muslim and Europeans beefeaters as 'impure' in the Muluki Ain (Law of the Land). One of the first acts of Prithivinarayan Shah after the conquest of Kathmandu Valley was the expulsion of Capuchin missionaries from Patan. He visualized Nepal as 'asil Hindustan' (pure land of Hindus). Since then, Hinduisation became the raison d'etre of the Nepalese state ${ }^{2}$.

The Muliki Ain - 1854 was a written version of social code that had been in practice for several centuries in Nepal. Its caste categories diverged from the four varna of the classical Vedic model and instead had three categories to accommodate the tribal peoples between the pure and impure castes. These were further classified into five hierarchies with the following order of precedence ${ }^{3}$.
A. Wearers of holy cord (caste)
B. Non-enslavable Alcohol-Drinkers (ethnic)
C. Enslavable Alcohol-Drinkers (ethnic)
D. Impure but touchable castes (ethnic, other caste \& outsiders)
E. Impure and untouchable castes (caste)

The scheme was biased in favour of dominant hill castes (Bahun, Thakuri, Chhetri). Though included in the first hierarchy (A) as pure, Indian (tarai) Brahman was ranked below Chhetri and Newar Brahman. Newar Brahman was similarly placed below the Chhetri. The second hierarchy (B) included Magar and Gurung, long associated with Gorkha regime, and also Sunuwar, who had received the lal mohar (royal seal) of being Hindu in 1825 . There was no reference to Rai and Limbu, the last tribals to succumb to the Gorkhali rule. The third hierarchy $(\mathrm{C})$ had Bhote, some smaller tribes and descendents of freed slaves (Gharti). The fourth (D) and fifth (E) hierarchies were considered impure castes with the distinction of the former as 'touchable' (no water sprinkling needed after contact) and the later as 'untouchable' (purification necessary after contact). Of the six included in ' $D$ ' hierarchy, four were Newar sub-groups, Muslim and Mlechh (European). The lowest hierarchy (E) had six artisan castes of the hill and two Newar 
scavenger sub-groups (Table1.1) The Muluki Ain was silent about the status of Madhise (tarai) castes, be it touchable or untouchable. There was discrimination in the extent of punishment for crimes according to the caste hierarchy of the person. The rule was one of higher penalty for those in upper hierarchies or the extent of penalty was tied to the level of ritual purity. For example, payment for divorce among the Newar had the following gradation ${ }^{4}$ :

\begin{tabular}{lc}
\hline Hierarchy & Sub-Group \\
\hline A. Shrestha (Hindu) & 70 \\
B. Bada (Buddhist) & 60 \\
B. Jyapu (Farmer) & 40 \\
B. Artisan castes (Hindu) & 35 \\
D. Impure but touchable (Mixed) & 15 \\
E. Impure and untouchable (Hindu) & 10 \\
\hline
\end{tabular}

The old legal code, Muluki Ain - 1854, was amended nine decades later in 1963 by repealing some penal clauses on untouchability. Further more, Nepal Constitution-1990 guarantees the rights to equality by stating that the State shall not discriminate against citizens on the basis of religion, colour, sex, caste, ethnicity or belief (Article 11.3). However, the above constitutional right is negated by a clause in the Muluki Ain as amended in 1992 which stresses that the traditional practices at religious places shall not be considered as discriminatory. This means that those castes once categorised untouchable would still have no access to shrines and temples. In the same way, adherence to 'traditional practices' would imply exclusion of untouchable castes and, therefore, inequality in other spheres also. Thus, caste discrimination and untouchability has remained a fact of everyday life in 'the world's only Hindu kingdom'

\section{Definition}

In recent years, the so-called disadvantaged or marginalised groups have emerged as a subject in Nepalese development discourse. Thus, the terms Janajati referring to ethnic people and Dalit referring to untouchable castes have come into currency. These two terms are not to be found in Muluki Ain as the former were labelled as Matwali (Alcohol-Drinker) and the latter as Pani Nachalnya (Untouchable). It might be useful here to make a subtle distinction of the native terms jat and jati although both mean the species ${ }^{5}$. Etymologically, jati is a derivative (feminine, weaker, sub-species) of the term jat (species, group). However, their general usage in Nepal is reversed: jati as ethnic group and jat as castes. This seems to reflect the reality of their relative political dominance. Following this convention, jat would refer to Hindu castes and jati to ethnic nationalities and Janajati as synonymous with jati. There is yet another structural difference between the caste and ethnic groups. Caste division is vertical, based on ritual hierarchy within the same racial/linguistic/ religious group. Nepalese Bahun and Badi represent the extremes of this continuum. On the other hand, ethnic division is horizontal or spatial. That is, ethnic group identity is based on specific native area, common language and religious tradition. The above distinction becomes useful in clarifying the term Dalit later.

The Hindi term Dalit had a recent entry in Nepal. But it had a longer exposure in India through two divergent personalities. Mahatma Gandhi (Vaisya) invented the term Harijan (God's people) for the Dalit untouchables and his approach was one of compassion and amelioration. The doyen of Dalit emancipation was B.R. Ambedkar, himself of untouchable caste, who had a hand in drafting the Constitution of India (1950) with recognition of Scheduled Castes for affirmative action. Dr. Ambedkar did not believe in Dalit emancipation within the Hindu caste system and 
therefore persuaded millions of Dalits into the egalitarian Buddhist fold beginning on 15 October 1956 at Nagpur ${ }^{6}$.

In Nepal, the confusion about who are the Dalit has been created by the Hindu regime and its ideologues. This is evident from the official reticence to recognise the specific identity of Dalit castes. Thus, they are subsumed under the rubric of such general terms as disadvantaged, downtrodden, marginalised and oppressed groups. Affirmative action was first referred in the Communist government's budget speech of July 1994 that recognized 16 social groups as 'oppressed class' including 11 low castes. The Coalition government budget speech of July 1995 referred to 12 'oppressed groups' of which 8 were low castes. None of these two statements specified who were the Dalit. Subsequently, a National Committee for Upliftment of Upechhit (Excluded), Utpidit (Suppressed) and Dalit (Exploited) was formed without specifying the target group. The Ninth Plan (1997 - 2002) had a separate section for Downtrodden and Oppressed Communities but with no definition or identification of who they are.

The Dalit Bikash Samiti formed in 1997 listed 23 social groups as the Dalit. Of these, only 15 were of the untouchable caste. Among those included were three Newar impure but touchable castes (Kasai, Kuche, Kusle), one tarai impure but touchable caste (Lohar) and one ethnic group (Santhal/Satar). The recent Government bill (19 March 2002) listing 28 social groups as Dalit is similarly erroneous. Among those scheduled in this list, Kasain, Kuche and Kusule Newars, and Lohar of tarai are impure but touchable castes. Jhangad as an Oraon ethnic group falls outside the caste category. Chunar, Parki and Sunar are sub-groups of Kami while Paswan is the same as Dusadh. Gothe and Thater remain unreported in the censuses. Thus, only 18 of the official list belong to the category of untouchable castes (Table 1.1). Of these, three are not recorded in the population census of 2001. Kadara could have been included among the Kami, their patrilineal caste. Chyame and Pode must have been included among the Newar.

The lack of clarity in the official definition owes to the diversity of opinion among researchers on the Dalit problem. There is no confusion as to the explicit meaning of Dalit as 'oppressed' but there is difference in interpretation. Some interpret the word Dalit as a derivative from daldal or swamp from where it is difficult to extricate ${ }^{7}$. In fact, the term Dalit has close etymological link with Nepali words dalai or dalnu which means to crush, exploit, oppress, or suppress. That expression can be applied to mean people who have been oppressed. The basis of such oppression, exploitation and exclusion of Dalits is caste discrimination.

According to one researcher, Dalit refers to "group of people who are religiously, culturally, socially and economically oppressed, who could belong to different language and ethnic groups" ${ }^{3,8}$. The multiple sources of oppression mentioned (religious, cultural, social, economic) above are as loaded as the much worded designation of the National Committee for Upechhit, Utpidit, Dalit Utthan. In fact, the oppression of Dalit castes emanates from their exclusion as social outcaste on ritual basis, which in effect marginalises them religiously, culturally and economically. It is misleading to assign untouchability on the basis of ethnicity or language since the Bahun and Kami belong to the same racial (Caucasoid), linguistic (Indo-Aryan), and cultural (Hindu caste) group. Therefore, Dalit term does not apply to those outside the caste system. That is why in India where the varna model as well as the Dalit term originated, the Constitution has two separate categories of backward communities for affirmative action: Scheduled Castes (715) and Scheduled Tribes (461). 


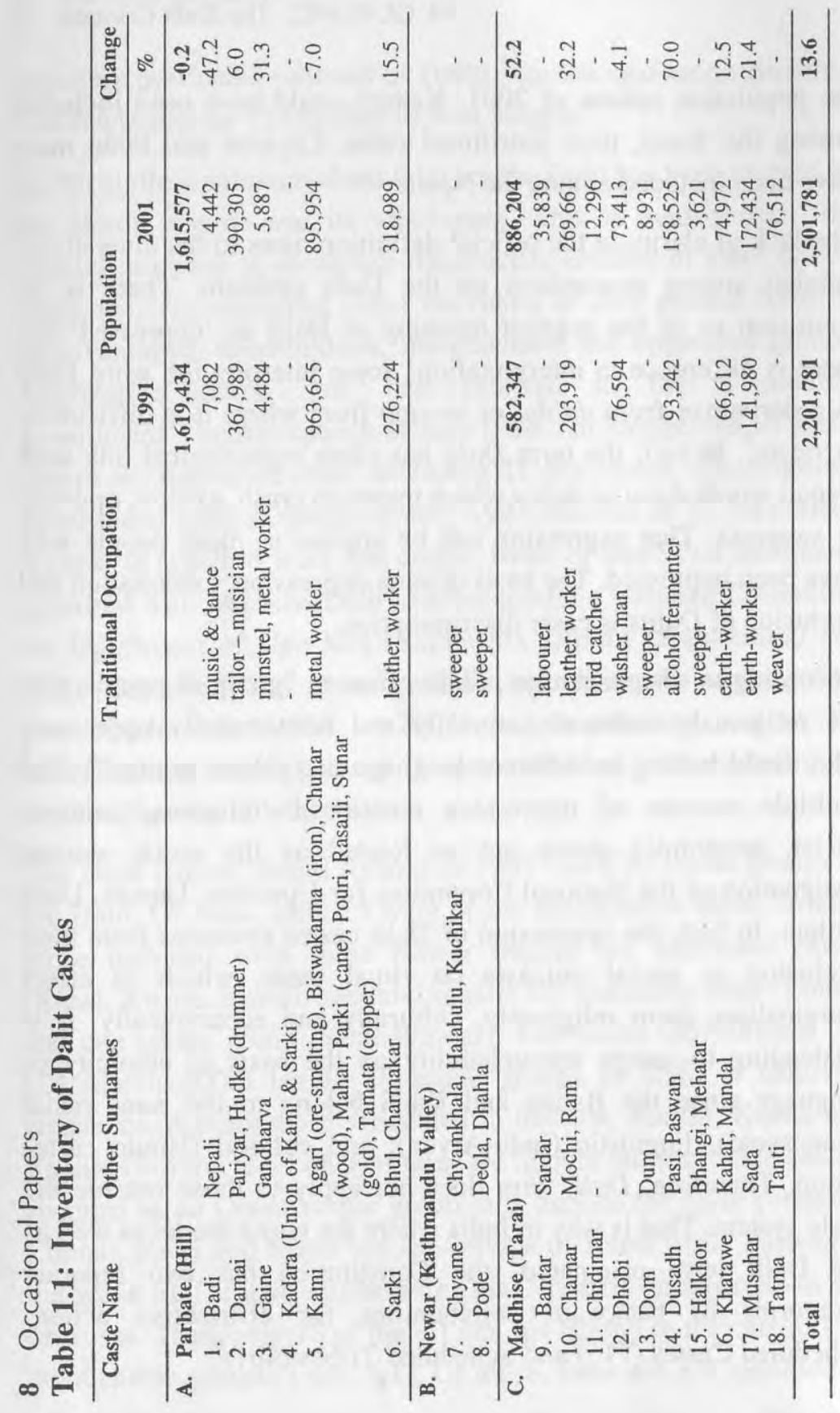

Another writer notes that "The word Dalit is used in Nepal to identify a vulnerable and poor group of people, who are discriminated against on the basis of their caste"1. This seems an realistic formulation by attributing vulnerability and poverty to caste discrimination. One Dalit writer is more specific to equate the term Dalit exclusively for the so-called 'untouchables' as defined in the old legal code of Nepal $(1854)^{2}$. However, the same writer enumerates a list of 63 Dalit groups including 8 ethnics and many tarai and Newar impure but touchable castes. Similarly, Dalit Sewa Sangha (Bikas Patrika, Vol. 9, No. 19, April 2001) claims the existence of 54 Dalit groups including 7 ethnics and 4 Newar touchable castes. Another Dalit writer gives a list of 25 Dalit groups among which 3 are ethnic, and 5 tarai and 2 Newar touchable castes $^{3}$.

One researcher clarifies that the term Dalit was chosen by their activists as a means of rejecting other derogatory terms such as 'untouchable', 'Scheduled Caste' or 'Depressed Class' ${ }^{\text {, }}$. Their equivalent terms in Nepali are achhut, kamsel, pani nachalne, sano jat, all referring to the untouchables. A recent report distinguishes two definitions regarding the Dalit, e.g. official one as broader variety of the oppressed and specific one in the sense of untouchable and subscribes to the latter specific one ${ }^{5}$. In other words, they are 'untouchable castes' of Nepal.

The present report considers that the Dalit term should be exclusively used to refer to the lowest hierarchy of the Hindu caste society, that is, those considered 'untouchable'. Such a definition would exclude ethnic groups, however, oppressed culturally and economically as they belong to entirely different social order. This would also exclude those considered impure but touchable Newar and Madhise castes among the Hindus. The term is similarly not applicable to non-Hindus as the Muluki Ain-1854 placed the 
Muslim and Mlechha (Christian) in the unclean but touchable hierarchy. Thus, Churaute (hill Muslim) and Buddhist Gara (butcher) cannot be considered Dalit (untouchable) since their religion do not recognise the caste system. Therefore, the Dalit category includes what one may call artisan or occupational castes among the Hindu and the term Dalit is an alternative to traditional ones with pejorative connotation for the bottom hierarchy of 'untouchable' Hindu castes. That they are socially ostracised, economically deprived, and politically excluded is the making of Hindu caste discrimination. These Dalit castes are listed in Table 1.1. There could be other castes treated as 'untouchable' but cannot be specified due to three reasons. First, the Muluki Ain was not definitive regarding the Madhesi castes of the tarai. Second, some surnames are synomys or clan (gotra) names to hide the Dalit status. Third, some caste names considered as Dalit are not reported in the population census and their provenance remains undertermined.

\section{Population}

The lack of clarity on the definition of Dalit obviously means diversity in data on the magnitude of their population. Although Nepalese decennial census began in 1911, ethnic/caste data were not reported until 1991. Thus, data on ethnic/caste composition of the population in Nepal are available only from 1991 and some studies of specific areas before that. One might refer to four such earlier studies. In 1957, an anthropological survey covered 33 Newar settlements of Kathmandu Valley ${ }^{6}$. In Newari, those in the untouchable category are called la cale ma ju pim or briefly ma ju pim (from whom water cannot be taken). Of the total 37,315 households, the caste breakdown was as follows:

\begin{tabular}{lcr}
\hline Caste & Households & \% \\
\hline 1. Newar, Brahman (Hindu) & 365 & 1.0 \\
2. Gubhaju, Banra (Buddhist) & 32,000 & 9.9 \\
3. Shrestha (Hindu) & 8,100 & 21.7 \\
4. Udas (Buddhist) & 1,700 & 4.6 \\
5. Jyapu (Indigenous) & 15,800 & 42.3 \\
6. Artisan castes (16) & 4,380 & 11.7 \\
7. Untouchable castes (6) & 2,470 & 6.6 \\
\hline Total & $\mathbf{3 7 , 3 1 5}$ & $\mathbf{1 0 0 . 0}$ \\
\hline
\end{tabular}

The second study was based on the inventory of land record of 1964 - 66 for the Central Development Region covering 19 districts of Janakpur, Narayani and Bagmati Zones?. It recorded 97 caste/ethnics with a total population of $3,468,816$. Among these, the following can be considered Dalit.

\begin{tabular}{|c|c|c|c|}
\hline Hill & Population & Tarai & Population \\
\hline 1. Badi & 216 & 1. Chamar & 34,069 \\
\hline 2. Damai & 37,497 & 2. Dom & 532 \\
\hline 3. Gaine & 261 & 3. Dusadh $(29,625)$ & 29,880 \\
\hline 4. $\operatorname{Kami}(53,093)$ & 49,736 & + Pasi $(255)$ & \\
\hline + Sunuwar $(15,389)$ & & 4. Khatwe & 8,489 \\
\hline \multirow[t]{3}{*}{ 5. Sarki } & 49,736 & 5. Tatma & 14,077 \\
\hline & & 6. Mester & 8,821 \\
\hline & & 7. Thater & 132 \\
\hline Total & 156,237 & Total & 96,000 \\
\hline
\end{tabular}

The above 12 Dalit castes had a population of 252,237 . Thus, they constituted 7.3 percent of the total population of Central Development region.

The third was a regional study of the then four districts of Jumla, Tibrikot, Mugu and Humla of Karnali Zone ${ }^{8}$. The census of 
landholdings by caste/ethnicity for $1969 / 70$ showed the following distribution pattern:

\begin{tabular}{lcc}
\hline Caste/Ethnicity & Population \% & Landholding \% \\
\hline Chhetri (including Matwali) & 41.1 & 47.7 \\
Thakuri (caste) & 18.0 & 21.1 \\
Bahun (caste) & 14.0 & 10.4 \\
Bhotia (ethnic) & 4.1 & 9.5 \\
Dum (untouchable) & 19.5 & 9.1 \\
Others & 3.3 & 2.3 \\
\hline Total & $\mathbf{1 0 0 . 0}$ & $\mathbf{1 0 0 . 0}$ \\
\hline
\end{tabular}

Accordingly, Karnali Zone with a population of 185,996 was composed of 73.1 percent high caste, 19.5 percent 'untouchable' Dum and $4: 1$ percent ethnic Bhotia. Of the total 14,959 hectare land, Chhetri and Thakuri held a higher proportion than their population share. Dum or Dalits constituting a fifth of total population had less than 10 percent of the total land holding.

The fourth survey was based on the sample of 5,643 households of 10 tarai districts in $1983^{9}$. The surveyed households represented 53 ethnic/caste groups. Among these, nine were Dalit castes. These Dalit households together made 465 , which comes to 8.2 percent of the total households covered.

\begin{tabular}{lclc}
\hline Hill & Households & Tarai & Households \\
\hline Damai & 10 & Chamar & 181 \\
Gaine & 1 & Dhobi & 34 \\
Kami + Sunar & 19 & Dom & 10 \\
Sarki & 15 & Dusadh + Pasi & 66 \\
& & Musahar & 119 \\
\hline Total & $\mathbf{5 5}$ & Total & $\mathbf{4 1 0}$ \\
\hline
\end{tabular}

The census of 1991 reported the population of only five hill and five tarai Dalit castes (Table 1.1). They totalled 2,201,781 or 11.9 percent of Nepal's population. Of all reported Dalits, 1.6 million or 73.6 percent were of hill caste, led by the Kami (16.7\%). It is possible that many Dalits were included among the category of 'others' which was reported as 184,216 among the hill and 627,514 among the tarai population. The census of 2001 reported the population of 15 Dalit castes. Of these, 5 were of hill and 10 of tarai (Table 1.1). The population of ten Dalit castes reported in 1991 increased to $2,291,577$ in 2001 . This meant 7.8 percent increase of Dalit population as against an average increase of 23.0 percent of the total population during the decade. There was also contrary regional trend: hill Dalits declined by 0.2 percent and tarai Dalits increased by 52.2 percent. The Dalit population increase in 2001 was accentuated with recording of 5 more tarai Dalit castes. Thus, the population increase of identified Dalit castes was 14.3 percent during 1991-2001. The 2001 census also recorded 173,401 as unidentified Dalit without any definition of the term Dalit ${ }^{10}$. If all these were Dalit, the total population of Dalits would be 2,601,769 or 11.4 percent of the total population classified by caste/ethnicity.

However, some Dalit writers claim that "the population of Dalits can be estimated between 16-20\% of the total national population" "I. The four sample studies and census data do not support such statement. According to the above sample studies, the proportion of Dalit population was 6.6 percent among the Newar of Kathmandu Valley, 7.3 percent in Central Development Region, 9.1 percent in Karnali Zone and 8.2 percent in 10 tarai districts for migration survey. In fact, there are two contrary tendencies regarding the population of Dalits. One is to inflate by including non-Dalits such as impure but touchable castes as well as some marginalised ethnic groups in official lists and writings for Dalit assertion. Another is the Dalit attempt to divest from their own 
identity for a higher status. For example, Kami (Biswakarma) constituted the largest group among the Dalit castes in census 1991. But there were 76,701 less Kami reported in 2001 (Table 1.1). This decline in Kami population was obviously not due to high mortality rate but their reporting under other caste, presumably higher. Similarly, the Badi population reported in 2001 is 47.2 percent less than that in 1991 (Table 1.1). One of the large caste group of tarai, Dhobi, also shows a population decline of 4.1 percent. In fact, the 14.3 percent increase of Dalit population between 1991 - 2001 was accentuated by addition of 137,352 as Bantar, Chidimar, Dom, Halkhor and Tatma that were not recorded in 1991. If these Dalit castes were to be excluded from the calculation, the increase of Dalit castes reported in 1991 and 2001 censuses would be only 7.8 percent, far below Nepal's average population increase of 23 percent for the same period. The conclusion is that the low number of Dalits can be attributed to their own disclaimer of being a Dalit for a higher caste status by adopting Brahmanic gotra (clan) designation or other caste names. Dalit castes will not be emancipated unless they rid themselves of such inferiority complex.

\section{Situation}

Whatever their population magnitude, the Dalit of Nepal remain socially excluded, economically exploited and politically suppressed. The source of such oppression is the State's religious ideology that sanctifies inequality based on caste. The revised Muluki Ain-1963 retains vestiges of discrimination with terms like 'high' and 'low' caste, religious segregation and vagueness in clauses on untouchability ${ }^{12}$. Since the Dalit plight is of least concern to higher castes, there is paucity of hard data on the extent of their deprivation. The data available on the education level and incidence of poverty provide clear evidence of the correlation between caste hierarchy, on one hand, and literacy and economic status, on the other. That is, lower the caste rank, higher the illiteracy and propensity to poverty ${ }^{13}$. According to the 1991 census, the literacy rate of Nepal was 39.3 percent. Of the 60 ethnic/groups then, 19 or one-third exceeded this average literacy level ${ }^{14}$. All of these were non-Dalit. Among the bottom ten with low literacy rate, 5 were Dalit, 3 ethnic and 2 other caste groups. Literacy rate of Chamar, Dusadh and Musahar was less than 11 percent. With literacy rate of 33.9 percent for male and 12.0 percent for female, the average literacy rate for the Dalit comes to 22.8 percent.

The 1991 census reported 96,977 persons having educational attainment of graduate and above level. Of these, only 3,034 or 3.1 percent belonged to Dalit castes. Thus, while high illiteracy limits the Dalit from access to higher education, the absence of such qualification restricts their entry into bureaucracy or better employment opportunity. It is obvious that Dalits are virtually absent in bureaucracy and institutions of national life ${ }^{15}$. There was not a single Dalit out of 762 persons as judges, senior bureaucrats, campus teachers and university staff as recorded by Nepal Institutional Manpower Directory, 1998. Similarly, out of 191 DDC chairpersons, mayors and 165 central party members of major parties, none was a Dalit. Out of 363 civil society leaders, only one was a Dalit. According to UNDP/Nepal source, there were only 4 Dalit out of 855 employees in multilateral donor institutions and donor projects $^{16}$. It is not surprising that out of 1,520 high level personnel included to derive an integrated national index of governance, there were only 5 persons or 0.3 percent of Dalit caste $^{17}$.

The Nepal Living Standard Survey - 1996 (NLSS) sampled 3,388 households that had a representation of only 14 ethnic/caste groups. The NLSS data of even this restricted coverage clearly evidence 
economic status being related to social hierarchy and literacy rate ${ }^{18}$. The survey showed that the country had 42.6 percent households below the poverty line (Table 1.2). Dalit caste households below the poverty line ranged from 65 to 68 percent and mostly ranked at the bottom. Of the four social groups with a higher proportion above poverty line, two were high caste, one partly Hinduised (Newar) and Muslim. The two top ranked social groups with onequarter to one-third poverty level were Newar and Bahun having the highest literacy rate. The three Dalit castes ranked very low in literacy and had high incidence of poverty. Muslim and Limbu were aberrations showing no nexus between poverty incidence and literacy rate. Overall, the Dalits had lower rate of literacy and higher incidence of poverty.

Table 1.2: Poverty Incidence and Literacy Rate

\begin{tabular}{lcrrr}
\hline \multirow{2}{*}{ Caste/Ethnicity } & \multicolumn{2}{c}{$\begin{array}{c}\text { Proportion below } \\
\text { poverty line (1996) }\end{array}$} & \multicolumn{3}{c}{$\begin{array}{c}\text { Literacy } \\
(\mathbf{1 9 9 1 )} \text { b }\end{array}$} \\
\cline { 2 - 6 } & Rank & \% & Rank & Rate \\
\cline { 2 - 5 } Newar* (40\% Hindu castes) & 1 & 25 & 2 & 60.4 \\
Bahun & 2 & 34 & 1 & 61.6 \\
Muslim & 3 & 38 & 14 & 22.2 \\
Yadav & 4 & 40 & 11 & 26.3 \\
Gurung* & 5 & 45 & 3 & 46.9 \\
Tharu* & 6 & 48 & 10 & 27.7 \\
Chhetri & 7 & 50 & 5 & 45.0 \\
Rai* & 8 & 56 & 6 & 44.5 \\
Magar* & 9 & 58 & 7 & 39.3 \\
Tamang* & 10 & 59 & 9 & 27.8 \\
Sarki & 11 & 65 & 13 & 24.2 \\
Damai & 12 & 67 & 8 & 27.9 \\
Kami & 13 & 68 & 12 & 26.0 \\
Limbu* & 14 & 71 & 4 & 46.8 \\
\hline NEPAL & - & 42.6 & - & 39.3 \\
\hline
\end{tabular}

* = Ethnic

Sources: a. NESAC, Nepal: Human Development Report, 1998, Table 7.24. b. CBS, Population Census - 1991, Vol. 1, Part VII, Table 26.
The livelihood problem of the Dalit is mainly due to lack of farmland as they are dependent on artisan occupation and wage work. Furthermore, their traditional skills are being made redundant with intrusion of mass produced goods and new technologies. It was noted above (p. 8) that Karnali Zone in $1969 / 70$ had 19.5 percent as Dalit population but their share in land holding was only 9.1 percent. Recent surveys show that land reform programme had made no dent in the skewedness of landholding. The extent of land hunger was found to be 39 percent among high caste and 64 percent among Dalits ${ }^{19}$. Almost one-third of Dalits were marginal farmers (with 3-9 ropani). As a consequence, the proportion of food deficit households was 88.3 percent among the Dalit compared to 56.7 percent among the high caste ${ }^{20}$. The per household income was found the highest among high castes and the lowest among the Dalit. The findings of the TEAM Consult study conclusively prove a high congruence between caste hierarchy and economic status.

The depressed status of the Dalit is evident from their low levels of literacy, low income, and low life expectancy. The fate of Dalit is one of a vicious circle. Caste discrimination marginalises them from economic opportunity, which in turn lead to further dependence and destitution. Since they are unable to compete economically and politically due to social exclusion, constitutional provisions pertaining to equality of opportunity remains a mere rhetoric. Therefore, such a condition of exploitation based on caste can be tackled only through the initiative of affirmative action.

\section{End Notes}

* Eleanor Zelliot, From Untouchable to Dalit, New Delhi: Manohar Publications, 1992

1. Padma Bishwakarma. "Nepalma dalit birudha jatiya bhedbhav tatha chhuvachhut", Durban Ghosana ra Karyayojana Thatha Nepalma 
Jatiye Bibhed, edited by Malla K. Sundar \& Padmalal Biswakarma, Kathmandu: NCARD, 2002, pp. 194 - 202.

2. Harka Gurung. "State and Society in Nepal", Nationalism and Ethnicity in a Hindu Kingdom, edited by David Gellner, Johnna PfaffCzarneka \& John Whelpton, Amsterdam, 1997, pp. 495 - 532.

3. Andras Hofer. The Caste Hierarchy and the State in Nepal: A Study of the Muluki Ain 1854, Innsbruck, 1979, p. 45.

4. Andras Hofer, op.cit,, p. 137.

5. Harka Gurung. Nepal: Social Demography and Expressions, Kathmandu: New ERA, 1998/2001, p. 35

6. Bhatnagar, R.M. Yugapurush Ambedkar (Biographical novel), Delhi: Rajpal \& Sons, 1994, p. 446.

7. Jit Gurung \& others. The conditions of the Dalits (Untouchables in Nepal): Assessment of Various Development Interventions. TEAM consult report to UNDP, 1999.

8. Bidya Nath Koirala. Schooling of Dalits of Nepal: A case study of Bungkot Dalit community. Ph.D dissertation, University of Alberta, 1996.

9. K.S. Singh. The Scheduled Castes (1993) and Scheduled Tribes (1994), Delhi: Anthropological Survey of India.

10. Sashi Rijal. "Foreword", Dalit in Nepal, An Alternative Report for WCAR 2001, Kathmandu: Jana Utthan Pratisthan, 2001.

11. Padmalal Biswakarma. "Dalit samudayako samajik, arthik, rajnaitik ra arakchhan ko sawal", Dalit Samudaya Samasya, edited by Padmalal Biswakarma \& Ambika Prasad Niraula, Kathmandu; National Consultation, 3-4 January 1998, pp. 20-43 (Definition and listing see pp. $26-27$ ),

12. Hira Viswakarma; "Dalits of Nepal: Their movement now and then", Dalits of Nepal: Issues and Challenges, edited by Prabodh M. Devkota, Kathmandu: FEDO, 2002, pp. 19 - 42 (see table. p.27).

13. Jit Gurung. Promotion of Sociocultural, Economic and Political Participation of Dalits and Other Disadvantaged Groups: A Strategic Approach (Draft). Submitted to the Enabling State Programme, Kathmandu, Oct. 2002, p.7.
14. D.R. Dahal \& others. National Dalit Strategy Report: Part I: Situation Analysis of Dalits in Nepal. Submitted to Action-Aid Nepal, CARE Nepal and Save the Children US., Kathmandu, April 2002, p.8.

15. Colin Rosser. "Social mobality in Newar caste system", in Caste \& Kin in Nepal, India \& Ceylon. Edited by C. von Furer-Haimendorf, Bombay, 1966 , pp. $68-139$ (see pp. $85-86$ ).

16. Walter Frank. Ethnographic Survey of Nepal, 2 Vols. Unpublished manuscript in mimeo.

17. Barry C. Bishop. Karnali Under Stress: Livelihood Strategies and Seasonal Rhythms in a Changing Himalaya, Chicago University Press, 1990, p. 176 (Table 9).

18. Harka Gurung \& others. Internal and International Migration in Nepal (in Nepali), Vol. V (Table 12.42), Kathmandu: National Commission on Population, 1983 (see Table 12.43).

19. CBS. Population Census, 2001: National Report, Kathmandu, June 2002, pp. 102-102 (Table 18).

20. Hira Biswakarma, 2002, op. cit. (Footnote no. 12) , p.27.

21. Padmalal Biswakarma, op. cit., (Footnote no. 1) p. 300

22. Harka Gurung. "Janajati and Dalit: The Subjugated in Governance". Readings on Governance and Development, Vol. II, 2003, pp. 1-13.

23. Harka Gurung, 1998/2001, op. cit., (Footnote no. 5) Appendix L.

24. Govind Neupane. Nepalko Jatiya Prasna (Ethnic Issues in Nepal), Kathmandu, 2000 , pp. $64-81$.

25. TEAM Consult. Study Report on Discrimination and Forced Labour of Occupational Castes in Nepal. Submitted to ILO, Nepal, October 2002.

26. Govind Neupane, op. cit. (Footnote no. 25), p.82

27. NESAC. Nepal: Human Development Report - 1998. Kathmandu: UNDP, 1998, Table 7.24

28. TEAM Consult, op. cit. (Footnote no. 25) p. 48

29. TEAM Consult, above, p. 204 


\section{References Cited}

Bhatnagar, R.M, 1994. Yugapurush Ambedkar (Biographical novel), Delhi: Rajpal \& Sons.

Bishop, Barry, 1990. Karnali Under Stress, Chicago.

Biswakarma, Hira, 2002. "Dalit in Nepal: Their movement now and then", PP 19-42, In Pramodha Devkota (ed) in Dalits in Nepal: Issues and Challenges, Kupondole: FEDO.

Biswakarma, Padmalal, 2002. "Nepal ma dalit birudh jatiya bhedbhav tatha chhuvachuut", pp 194-202, In Malla K. Sundar and Padmalal Bishwakarma (eds) Durban Ghosana ra Karyayojana Tatha Nepal ma Jatiya Bibhed, Kathmandu: NCARD.

Dahal, Dilli Ram \& Others. 2002. National Dalit Strategy Report, Part I: Situational Analysis of Dalits in Nepal. Kathmandu: Action-Aid Nepal, CARE Nepal and Save the Children US.

Frank, Walter, Ethnographic Survey of Nepal, 2 Vols. Unpublished manuscript in mimeo.

Gurung, Harka, 1997. "State and Society in Nepal". Pp 495-532, In David Gellner, Johnna Pfaff-Czarneka \& John Whelpton (eds) Nationalism and Ethnicity in a Hindu Kingdom. The politics of Culture in Contemporary Nepal. The Neatherlands: Harwood Academic Press.

1998/2001.Nepal: Social Demography and Expressions, Kathmandu: New ERA.

2003. "Janajai and Dalit: The Subjugated in Governance," Readings on Governance and Development, Vol. II, pp. 1-13.

and others, 1983. Internal and International Migration in Nepal, Kathmandu: National Commission on Population,

Gurung, Jit, 2002. Promotion of Socio-cultural, Economic and Political Participation of Dalits and other Disadvantaged Groups: A Strategic Approach (Draft). Submitted to the Enabling state Programme, Kathmandu. and others, 1999. The Condition of the Dalits (Untouchables) in Nepal: Assessment of the Impact of Various Development Interactions. Submitted by TEAM Consult to UNDP.

Hofer, Andras, 1979. The Caste hierarchy and the State in Nepal: A Study of the Muluki Ain 1854, Innsbruck.

Koirala, Bidyanagth, 1996. Schooling of Dalits in Nepal: A Case Study of Bungkot Community, Ph.D. dissertation, University of Alberta,.

NESAC., 1998. Nepal Human Development Report - 1998, Kathmandu: UNDP.

Neupane, Govind, 2000. Nepal Ko Jatiya Prasna (Ethnic Issues in Nepal), Kathmandu.

Rijal, Sashi, 2001. "Foreword", Dalit in Nepal: An Alternative Report for WCARV2001, Kathmandu: Jan Utthan Prastishan.

Rosser, Colin, 1966. "Social mobility in Newar caste system", pp 68-139, In C. von Furer Haimendorf (ed) Caste and Kin in Nepal, India \& Ceylon. Bombay.

Singh, K.S, 1993. The Scheduled Castes, Delhi: Anthropological Survey of India.

1994. The Scheduled Tribes, Delhi: Anthropological Survey of India.

TEAM Consult, 2002. Study Report on Discriminatin and Forced Labour of Occupational Castes in Nepal. Submitted to ILO/Nepal, Kathmandu.

Zelliot, Eleanor, 1992. From Untouchable to Dalit, New Delhi: Manohar Publications. 